\title{
DISTRIBUTION OF PHOSPHORUS IN BED SEDIMENTS OF THE WINOOSKI RIVER WATERSHED, VERMONT, 1997
}

\section{Amounts of phosphorus in Lake} Champlain must be reduced in order to improve the health and recreational value of the Lake. An understanding of how phosphorus is distributed in the Lake Champlain watershed is necessary to develop effective policies to reduce phosphorus. The U.S. Geological Survey collaborated with university and State agency staffs in Vermont to study the distribution of phosphorus in bed sediments.

\section{IMPORTANT FINDINGS}

- Concentrations of phosphorus in bed sediment generally increased from the headwaters of the Winooski River to the watershed outlet.

- Average concentrations of phosphorus in bed sediments were 20 percent higher in urban and agricultural areas than in forested areas.

- Fine-grained bed sediment (silt and clay) had 60 percent higher concentrations of phosphorus, on average, than coarse-grained bed sediment (sand).

- Flow regime strongly influenced sediment grain size. Bed sediment in impoundments consisted of fine sand, silt, and clay, whereas sediment in depositional zones in freeflowing reaches of streams consisted of medium and fine sands.

\section{BACKGROUND}

Phosphorus is an essential element of all living organisms and is often the limiting nutrient for plant growth in fresh waters. An estimated four-fold increase in phosphorus loadings to Lake Champlain since the early 19 th century has resulted in accelerated algal and plant growth in the Lake (Smeltzer and Quinn, 1996). Human activities are responsible for elevated phosphorus levels in Lake Champlain. Anthropogenic sources of phosphorus include municipal and industrial wastewater discharges, and urban and agricultural runoff. Since implementation of the Clean Water Act of 1972, a ban on phosphate detergents, controls on agricultural runoff, and the construction of phosphorus-removal facilities at municipal and industrial treatment plants have helped control phosphorus inputs to

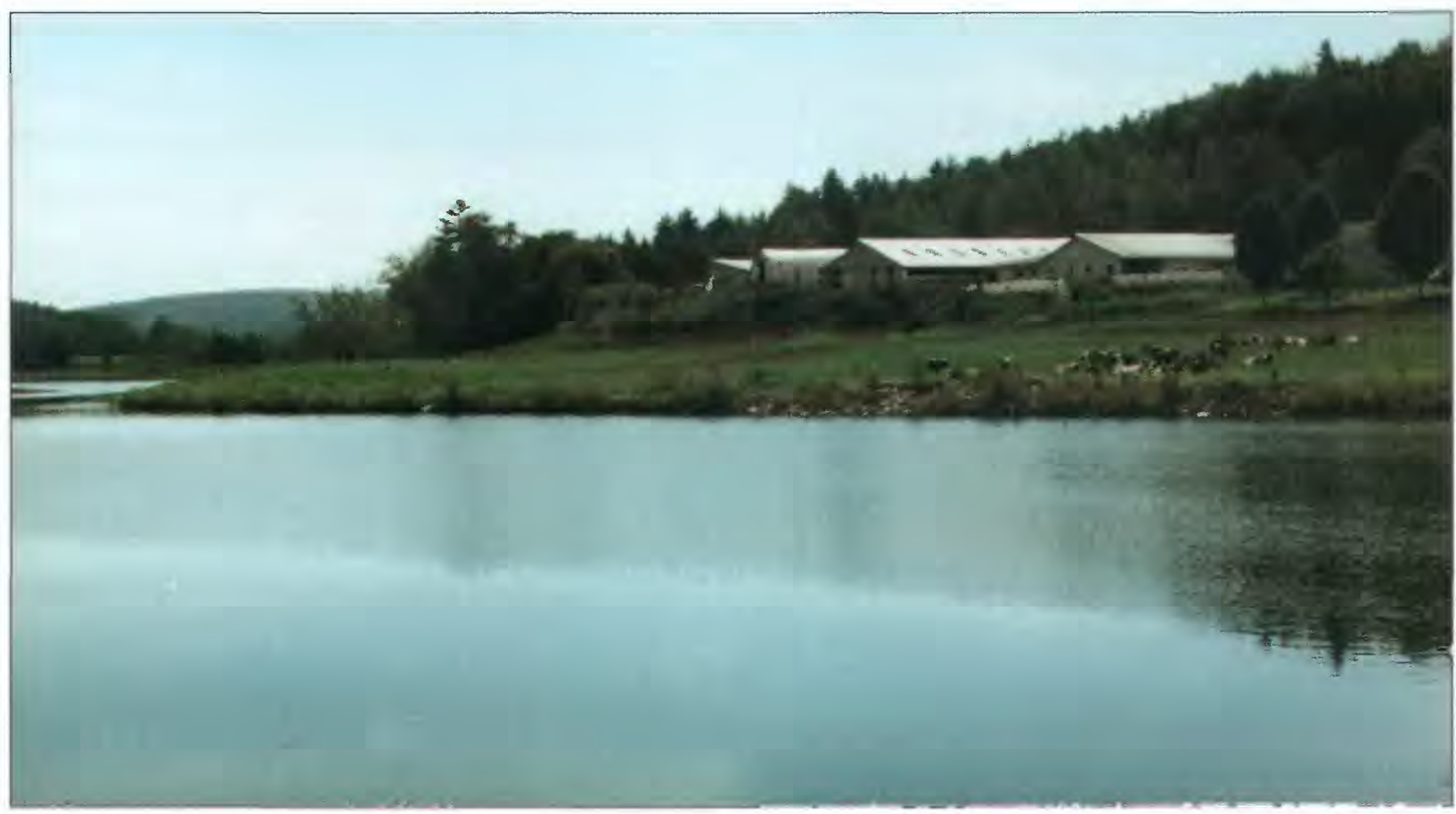

A typical dairy farm along the banks of the Winooski River, Mlddlesex, Vermont. 
the Lake. Despite the reductions, Lake Champlain continues to have nuisance levels of algal growth. Recent lake water-quality standards endorsed by the States of Vermont and New York, and by the province of Quebec, in the 1993 Lake Champlain Water-Quality Agreement, require additional reductions in phosphorus loadings to Lake Champlain (Smeltzer and Quinn, 1996).
An understanding of the cycling, storage, and transport of phosphorus in the Lake Champlain watershed is necessary to evaluate the effectiveness of phosphorus-reduction policies. The University of Vermont (UVM), School of Natural Resources, and the Vermont office of the Natural Resources Conservation Service (NRCS) are using dynamic simulation and mass-balance modeling techniques to evaluate the dynamics of phosphorus in tributary watersheds of Lake Champlain (Cassell and others, 1997). The initial focus of the modeling effort is on the Winooski River watershed. The 2,828-square kilometer Winooski River watershed is the largest tributary basin to Lake Champlain, has the greatest population (Henson and Gruendling, 1977), and contributes the second largest total

\section{EXPLANATION}

Phosphorus concentration in sediment (Number refers to sample site)

$\nabla_{8}$ Less than 800 milligrams per kilogram

Urban

Agriculture

Forest

$\nabla_{21}$ Greater than 1,000 milligrams per kilogram
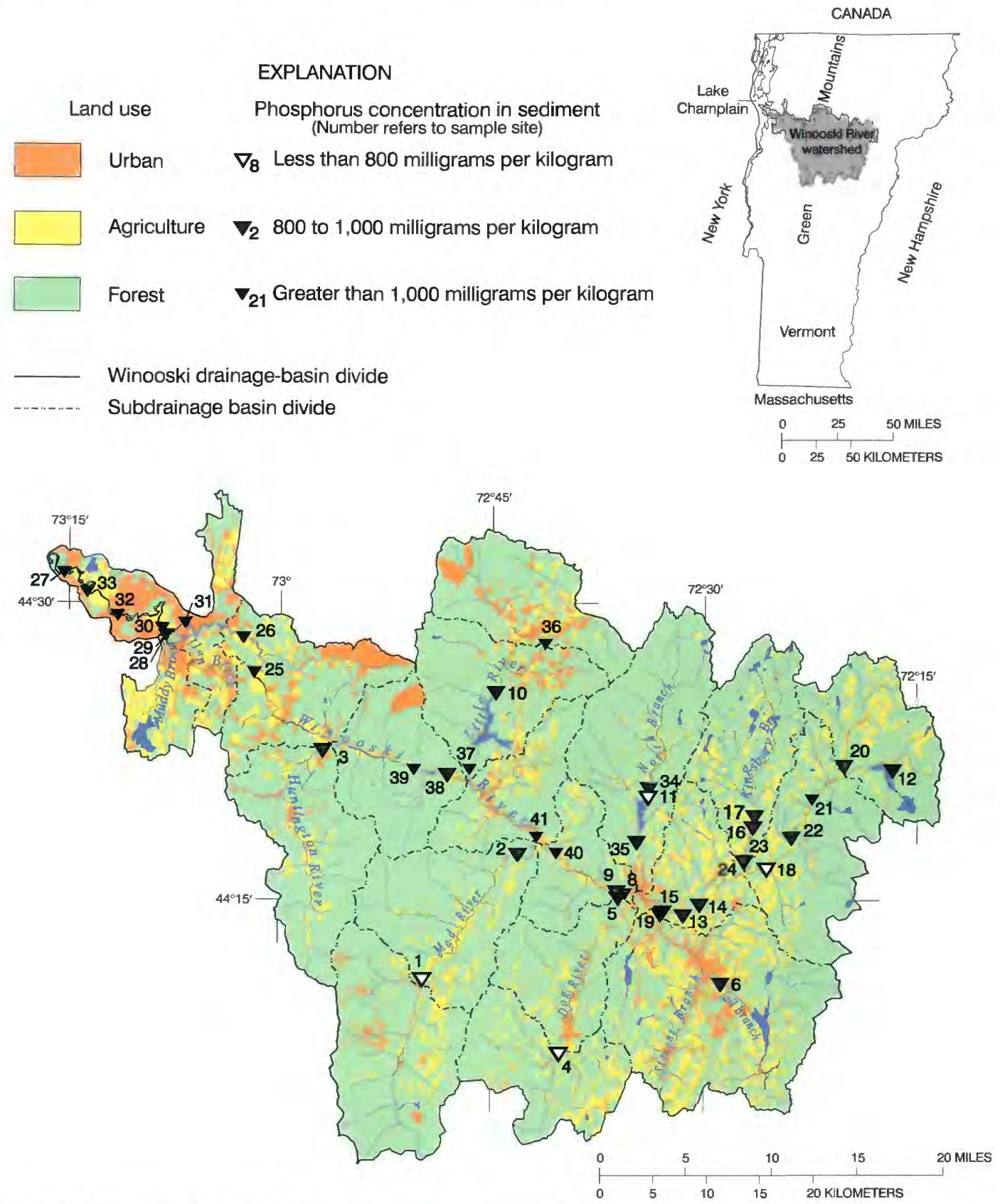

Base from a cooperative digital project of the University of Vermont, Natural Resources Conservation Service, and the U.S. Geological Survey
Land use from Central Vermont Regional Planning Commission, Chittenden Regional Planning Commission, Stone Environmental Consultants, and USGS GIRAS, 1973-95

Figure 1. Land use, sampling sites, and phosphorus concentration in sediment in the Winooski River watershed. 
phosphorus (TP) load of any watershed entering Lake Champlain (Smeltzer and Quinn, 1996). The U.S. Geological Survey (USGS) in collaboration with UVM and NRCS, has undertaken a study to collect the data needed for dynamic-simulation modeling of phosphorus in streambed sediments in the Winooski River watershed.

Previous studies have analyzed TP in fine-grained bed sediment at the mouths of tributaries to Lake Champlain (Colman and Clark, 1992) and in the Connecticut, Housatonic, and Thames River watersheds (Harris, 1997). Concentrations of TP in bed sediment measured by Colman and Clark (1992) ranged from 800 to 1,800 milligrams per kilogram (mg/kg), except at two sites on Mill Brook in New York, where concentrations were 3,300 and $3,500 \mathrm{mg} / \mathrm{kg}$. Samples of bed sediments near the mouth of the Winooski River contained 1,100 and $1,200 \mathrm{mg} / \mathrm{kg}$ TP. Harris (1997) found TP concentrations in fine-grained bed sediment ranging from $1,100 \mathrm{mg} / \mathrm{kg}$ in Vermont to $5,100 \mathrm{mg} / \mathrm{kg}$ near Hartford, Conn. Sites that drained areas from 62 to 97 percent urban and agricultural land had a median TP concentration of $2,200 \mathrm{mg} / \mathrm{kg}$ compared to a median concentration of $1,600 \mathrm{mg} / \mathrm{kg}$ for sites that drained areas of 83 to 91 percent forested land.

This report describes the distribution of total phosphorus in streambed sediment and identifies some factors controlling total phosphorus distribution in the Winooski River watershed.

\section{OBJECTIVES}

The principal objectives of the study described here were to:

1. Assess the distribution of TP in bed sediment in the Winooski River watershed.

2. Determine the extent of TP in fineand coarse-grained bed sediment.

3. Determine the relation(s) between concentrations of TP in sediment and watershed features such as land use, soil drainage class, basin slope, and streamflow regime.

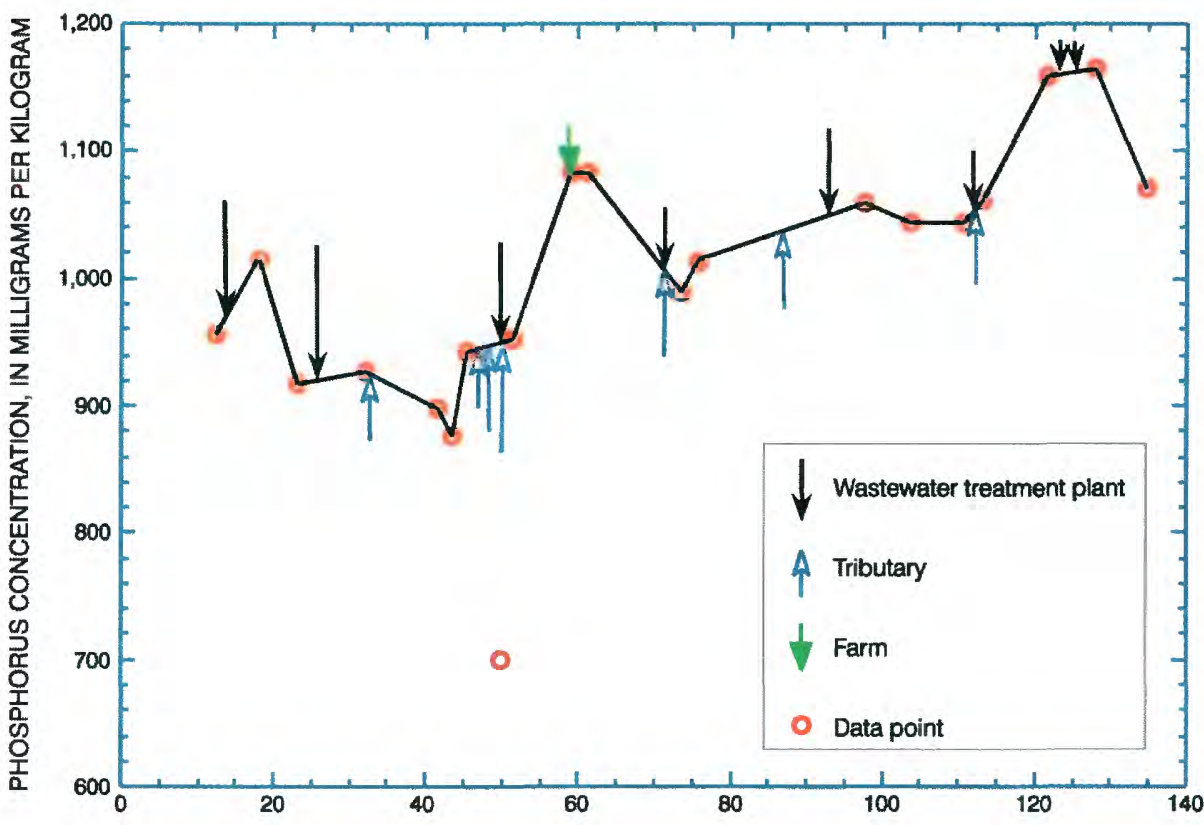

DISTANCE DOWNSTREAM FROM HEADWATERS, IN KILOMETERS

Figure 2. Concentration of phosphorus in fine-grained-bed sediment in the Winooski River,

\section{WATERSHED CHARACTERIZATION AND SAMPLING SITE SELECTION}

The Winooski River watershed was classified with respect to land use, soil type, basin slope, and flow regime with available Geographic Information System (GIS) data. Land-use data consisted of percentages of forested, agricultural, and urban land; soil drainage class specified either poorly to very poorly drained, or somewhat poorly drained to excessively drained; and basin slopes were designated as either $0-5$ percent or greater than 5 percent. The classification of flow regime referred to whether the site was impounded or free flowing. Land-use data were a compilation of three land-use data sets from Washington, Chittenden, and Lamoille Counties, merged with a 1:250,000 scale 1973-76 USGS Geographic Information Retrieval Analysis System data set (Cassell and others, 1997). Forested, agricultural, and urban land uses comprise $77,13.5$, and 7.6 percent of the watershed area, respectively. Most of the urban development, and much of the agricultural land, is located along the flood plains of the Winooski River and its major tributaries (fig. 1). Slope information was generated from a USGS Digital Elevation Model (DEM) for Lake Champlain at a scale of 1:250,000 (accessed on June 20, 1997 at http://edcwww.cr.usgs.gov/doc/ edchome/ndcdb/ndcdb.html). Seventytwo percent of the watershed had slopes of 0 to 5 percent. Most of the areas with slopes greater than 5-percent were in the middle of the watershed, which is dominated by the Green Mountains. Soils data came from NRCS soil surveys that were digitized by NRCS for the Vermont Center for Geographic Information (1997). Eleven percent of the watershed had poorly to very poorly drained soils. The poorly drained soils were primarily in the headwaters and near the watershed outlet.

Forty sampling sites were selected to represent a range of watershed characteristics (fig. 1). The land-use classification assigned to each site was based on the primary land use in the river corridor or flood plain directly upstream from the site, not that of the entire hydrologic subbasin of the site. Soil drainage and slope classification for each site is based on the soil and slope data for the hydrologic subbasin of the site (Vermont Center for Geographic Information, 1997). 


\begin{tabular}{|c|c|c|c|c|c|c|}
\hline \multirow[b]{2}{*}{$\begin{array}{l}\text { Bed- } \\
\text { sedi- } \\
\text { ment } \\
\text { site } \\
\text { number }\end{array}$} & \multirow[b]{2}{*}{ Bed-sediment site name } & \multicolumn{4}{|c|}{ Site characteristics } & \multirow[b]{2}{*}{$\begin{array}{l}\text { Total phospho- } \\
\text { rus in fine bed } \\
\text { sediment } \\
\text { (milligrams per } \\
\text { kilogram) }\end{array}$} \\
\hline & & Land use & $\begin{array}{l}\text { Percent of } \\
\text { subbasin } \\
\text { with } \\
\text { poorly } \\
\text { drained } \\
\text { soils }\end{array}$ & $\begin{array}{l}\text { Percent of } \\
\text { subbasin } \\
\text { with less } \\
\text { than } 5 \text { per- } \\
\text { cent slope }\end{array}$ & Flow regime & \\
\hline 20 & Winooski River above Mollys Brook near Marshfield & Agriculture & 26 & 88 & River & 957 \\
\hline 12 & Mollys Falls Pond at Mollys Brook inlet near Cabot & Forest & 26 & 88 & Impoundment & 888 \\
\hline 21 & Winooski River above Beaver Meadow Brook near Marshfield & Agriculture & 24 & 86 & River & 1,016 \\
\hline 22 & Winooski River above Nasmith Brook near Plainfield & Agriculture & 24 & 86 & River & 917 \\
\hline 18 & Great Brook at mouth at Plainfield & Agriculture and forest & 24 & 86 & River & 711 \\
\hline 23 & Winooski River above Kingsbury Branch near Plainfield & Agriculture & 24 & 86 & River & 928 \\
\hline 17 & Kingsbury Branch above North Montpelier Pond near North Montpelier & Agriculture & 12 & 91 & River & 871 \\
\hline 16 & North Montpelier Pond at Kingsbury Branch inlet at North Montpelier & Forest & 12 & 91 & Impoundment & $\begin{array}{r}952 \\
\text { split } 963\end{array}$ \\
\hline 24 & Kingsbury Branch at mouth near Plainfield & Agriculture & 12 & 91 & River & 872 \\
\hline 14 & Winooski River above Levesque Dam Pool near East Montpelier & Agriculture & 20 & 96 & River & 899 \\
\hline 13 & Winooski River at Levesque Dam near East Montpelier & Forest & 20 & 96 & Impoundment & 877 \\
\hline 15 & Winooski River below Levesque Dam Pool near Montpelier & Urban & 20 & 96 & River & 942 \\
\hline 6 & Jail Branch near Websterville & Forest & 20 & 88 & River & 864 \\
\hline 19 & Stevens Branch at mouth near Montpelier & Urban & 19 & 90 & River & 1,087 \\
\hline 34 & North Branch Winooski River near Worcester & Agriculture & 6 & 70 & River & 860 \\
\hline 11 & Wrightsville Detention Reservoir at North Branch inlet near Worcester & Forest & 6 & 70 & Impoundment & 772 \\
\hline 35 & North Branch Winooski River at Wrightsville & Forest & 6 & 70 & River & 829 \\
\hline 8 & Winooski River at Montpelier & Urban & 3 & 71 & River & 697 \\
\hline 4 & Dog River below Bull Run near Northfield & Agriculture and forest & 8 & 70 & River & 652 \\
\hline 5 & Dog River upstream of Waste Water Treatment Plant near Montpelier & Agriculture and forest & 3 & 64 & River & 978 \\
\hline 9 & Winooski River below Dog River near Montpelier & Urban & 3 & 71 & River & 952 \\
\hline 40 & Winooski River above Middlesex Dam near Waterbury & Agriculture & 3 & 71 & Impoundment & $\begin{array}{r}1,180 \\
\text { replicate } 985\end{array}$ \\
\hline 1 & Mad River at Waitsfield & Forest & 6 & 50 & River & 794 \\
\hline 2 & Mad River hydro pool near Moretown & Forest & 5 & 63 & Impoundment & 804 \\
\hline 41 & Winooski River below Mad River near Waterbury & Agriculture and forest & 4 & 65 & River & 1,083 \\
\hline 36 & Little River below West Branch at Stowe & Urban & 2 & 65 & River & 1,123 \\
\hline 10 & Waterbury Reservoir at Little River inlet near Stowe & Forest & 3 & 52 & Impoundment & 898 \\
\hline 37 & Little River near mouth near Waterbury & Forest & 3 & 52 & River & 1,023 \\
\hline 38 & Winooski River above Bolton Falls near Waterbury & Agriculture & 2 & 40 & Impoundment & $\begin{array}{r}989 \\
\text { split } 989\end{array}$ \\
\hline 39 & Winooski River below Bolton Falls near Bolton & Forest & 2 & 40 & River & 1.012 \\
\hline 3 & Huntington River near mouth at Jonesville & Forest & 5 & 49 & River & 970 \\
\hline 25 & Winooski River above Railroad Bridge near Williston & Agriculture & 11 & 79 & River & 1,059 \\
\hline 26 & Winooski River above North Williston Road Bridge near Williston & Agriculture & 11 & 79 & River & 1,045 \\
\hline 31 & Winooski River at Essex 19 Dam Pool at Essex Junction & Urban & 23 & 100 & Impoundment & $\begin{array}{r}1,058 \\
\text { replicatel, }, 032\end{array}$ \\
\hline 29 & Allen Brook at mouth near Essex Junction & Agriculture & 23 & 100 & River & 1,067 \\
\hline 28 & Muddy Brook at mouth near Essex Junction & Agriculture & 24 & 97 & River & 1,116 \\
\hline 30 & Winooski River near Essex Junction & Agriculture & 24 & 100 & River & 1,062 \\
\hline 32 & Winooski River below Chase Mill at Burlington & Urban & 24 & 100 & River & 1,159 \\
\hline 33 & Winooski River at Ethan Allen Homestead near Burlington & Agriculture & 24 & 100 & River & 1,165 \\
\hline 27 & Winooski River at Highway 127 Bridge near Colchester & Agriculture and forest & 24 & 100 & River & 1,071 \\
\hline
\end{tabular}




\section{DATA COLLECTION AND ANALYSIS}

Samples of bed sediments were collected using USGS National Water-Quality Assessment Program protocols (Shelton and Capel, 1994) during low flow in the summer of 1997. Samples were collected in zones of sediment deposition because fine-grained sediment and organic matter are natural accumulators of phosphorus. Homogenized composite samples were sieved to collect a fine-grained sample (sediment that passed through a 62-micron-sieve diameter). At selected sites, a coarse-grained sample (sediment that passed through a 2-millimeter-sieve diameter but did not pass through a 62-micron-sieve diameter) and a sample for grain-size analysis (sediment that passed through a

2-millimeters-sieve diameter) were also collected. Grain-size distribution was analyzed by the USGS Louisiana District Sediment Laboratory. Samples were dried, crushed, and analyzed for TP by acid persulfate digestion and phosphomolybdate determination of phosphorus concentration at the National Water Quality Laboratory in Arvada, Colo. (Fishman and Friedman, 1989).

\section{DISTRIBUTION OF PHOSPHORUS IN THE WATERSHED}

The median concentration of total phosphorus in fine bed sediment in the Winooski River watershed was $957 \mathrm{mg} / \mathrm{kg}$. The concentrations ranged from 652 to $1,180 \mathrm{mg} / \mathrm{kg}$ TP (table 1 ), which corresponded to TP concentrations found in bed sediment in similar locations in other studies (Colman and Clark, 1992; Harris, 1997). In the main stem of the Winooski River, concentrations of TP generally increased from the headwaters to the watershed outlet (fig. 2). The downstream increase in concentration is probably the result of a cumulative effect of runoff from agricultural and urban land, and discharge from wastewater treatment plants. The highest concentration of phosphorus $(1,180 \mathrm{mg} / \mathrm{kg})$ was detected in a sediment sample from the Winooski River adjacent to a dairy farm where cows were standing in the river. Samples with the next highest concentrations $(1,159$ and $1,165 \mathrm{mg} / \mathrm{kg}$ ) were collected in large urban areas near the watershed outlet, and downstream from several large wastewater treatment plants. Bed sediments in tributaries generally had similar or lower concentrations of TP than sediments in the main stem, with the exception of the Stevens Branch, which flows through a large urban area (table 1).

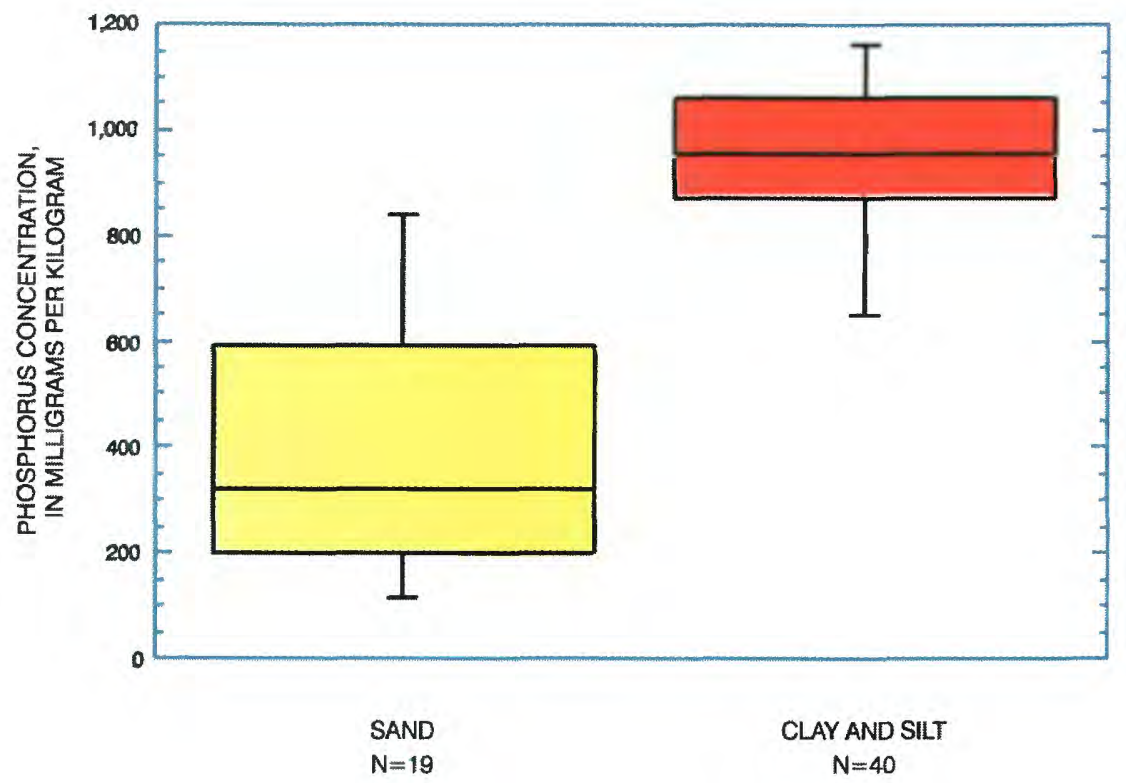

Figure 3. Phosphorus concentration as a function of grain size in bed sediment in the Winooski River watershed, Vermont. (N equals number of samples collected and analyzed to construct the box plots.)

Sites classified as urban had a median TP concentration of $1,045 \mathrm{mg} / \mathrm{kg}$, whereas those classified as agricultural and forested had median concentrations of $1,002 \mathrm{mg} / \mathrm{kg}$ and $882 \mathrm{mg} / \mathrm{kg}$, respectively. The relation between TP concentration in bed sediment and land use was most apparent in the small tributary watersheds with the least amount of mixed land use. Bed sediment in tributaries in heavily urbanized and agricultural areas had a median bed-sediment TP concentration of $1,087 \mathrm{mg} / \mathrm{kg}$, whereas sediment in tributaries in predominantly forested areas had a median concentration of $829 \mathrm{mg} / \mathrm{kg}$. No relation was apparent between TP concentration in fine-grained bed sediment and soil drainage class, basin slope, or flow regime. Median concentrations of TP were 986 $\mathrm{mg} / \mathrm{kg}$ for sites with poorly drained soils and $952 \mathrm{mg} / \mathrm{kg}$ for sites with well drained soils. Median concentrations of TP were $957 \mathrm{mg} / \mathrm{kg}$ for areas with slopes primarily less than 5 percent and 978 $\mathrm{mg} / \mathrm{kg}$ for areas with slopes predominantly greater than 5 percent. Median TP concentrations at impounded and freeflowing sampling sites were $898 \mathrm{mg} / \mathrm{kg}$ and $970 \mathrm{mg} / \mathrm{kg}$, respectively.

\section{RELATION OF GRAIN SIZE TO PHOSPHORUS CONCENTRATION AND FLOW REGIME}

Grain-size distribution data for bed sediment collected in depositional areas in streams and impoundments in the Winooski River watershed were analyzed to determine the relation of grain size to concentrations of TP and flow regime. A complete listing of grain-size analysis, TP concentrations, and field data is available in Coakley and others (1998). The median concentration of $957 \mathrm{mg} / \mathrm{kg} \mathrm{TP}$ in fine-grained sediment (silt and clays) was nearly three times greater than the median TP concentration of $323 \mathrm{mg} / \mathrm{kg}$ found in coarse-grained sediment (sands) (fig. 3). Median grain-size distributions for free-flowing sites were 6 percent coarse sand, 46 percent medium sand, 48 percent fine sand, and 2 percent silt/clay. Median grain-size distributions for the impounded sites were 2 percent coarse and medium sand, 75 percent fine sand, and 13 percent silt/clay. 


\section{SUMMARY AND CONCLUSIONS}

The concentration of total phosphorus in the fine-grained bed sediment of the Winooski River watershed showed a general increase downstream from the headwaters to the watershed outlet. This increase is probably the cumulative effect of the additions of phosphorus in runoff from agricultural and urban land and discharge from wastewater treatment plants. Land use appeared to be the dominant factor influencing TP distribution in sediment. Concentrations of TP were higher in bed sediment in heavily urbanized and agricultural areas than in sediments in forested areas. Concentrations of TP in bed sediment in the Winooski River watershed appear to be related to grain size; silt and clays had much higher concentrations than sands. The flow regime in the Winooski River watershed strongly influences grain-size distribution of bed sediments. Sediments in impoundments consist almost entirely of deposits of fine sand, silt and clay, whereas sediments in depositional zones in free flowing reaches of streams consist of medium and fine sands. The high percentage of silt and clay in impoundments, combined with high concentrations of TP in silt and clay, suggests that there is a significant potential for storage of phosphorus in impoundments that could be an important factor in predicting the dynamics of TP loads in the watershed.

\section{REFERENCES}

Cassell, E.A., Kort, R.L., and Braun, D.L., 1997, The VermontLake Champlain Basin Watershed Phosphorus Management Study: Dynamic simulation modeling for watershed ecosystem analysis of phosphorus budgets, Phase I final draft: Burlington, Vt., School of Natural Resources, University of Vermont, and Winooski, Vt., Natural Resource Conservation Service, U.S. Department of Agriculture, $178 \mathrm{p}$.

Coakley, M.F., Olimpio, J.R., Kiah, R.G., and Ward, S.L., 1998, Water resources data, New Hampshire and Vermont, water year 1997: U.S. Geological Survey Water-Data Report NH-VT-97-1, $180 \mathrm{p}$.

Colman, J.A., and Clark, Jr., S.F., 1992, Geochemical data on concentrations of inorganic constituents and polychlorinated biphenyl congeners in streambed sediments in tributaries to Lake Champlain in New York, Vermont, and Quebec: U.S. Geological Survey Open-File Report 94-472, 65 p.

Fishman, M.J., and Friedman, L.C., 1989, Methods for determination of inorganic substances in water and fluvial sediments, U.S. Geological Survey: Techniques of WaterResources Investigations, book 5 , chap. A1, p. 367-370.
Harris, S.L., 1997, Inorganic and organic constituents and grain-size distribution in streambed sediment and ancillary data for the Connecticut, Housatonic, and Thames River Basins study unit, 1992-94: U.S. Geological Survey Open-File Report 96-397, 39 p.

Henson, E.B., and Gruendling, G.K., 1977, The tropic status and phosphorus loadings of Lake Champlain: EPA-600/3-77-106, 14 I p.

Shelton, L.R., and Capel, P.D., 1994, Guidelines for collecting and processing samples of stream bed sediment for analysis of trace elements and organic contaminants for the National Water-Quality Assessment program: U.S. Geological Survey Open-File Report 94-458, $20 \mathrm{p}$.

Smeltzer, Eric, and Quinn, Scott, 1996, A phosphorus budget, model, and load reduction strategy for Lake Champlain: Journal of Lake and Reservoir Management, v. 12, issue 3, p. 383-385.

Vermont Center for Geographic Information, 1997, Catalog summary: Burlington, Vt., University of Vermont, $63 \mathrm{p}$.

—Ann T. Chalmers

For more information, please contact:

Ann T. Chalmers

U.S. Geological Survey

P.O. Box 628

Montpelier, VT 05601

(802) 828-4511

FAX (802) 828-4465

Email chalmers@usgs.gov

Visit the U.S. Geologica/ Survey website at http://www.usgs.gov/ or our website at http://bowdnhbow.er.usgs.gov/. 